\title{
Study on Intersubjectivity and Intertextuality in Reviewing the Woman Warrior
}

\author{
Xue $\operatorname{Han}^{1, a}$ and Weina Ouyang ${ }^{1, b^{*}}$ \\ ${ }^{1}$ Education Institute, Beihua University of Jilin 132000, China \\ a531252685@qq.com, b694839505@qq.com \\ * the corresponding author
}

Keyword: Woman warrior; Intersubjectivity; Intertextuality; Transcendental Phenomenology

\begin{abstract}
Without form and content, the context is what we can grasp, the classical Chinese-American works The Woman Warrior is an exactly proper example, In terms of intersubjectivity and intertextuality, individuality and community of subjects can coexist with each other, the female character in the novel, originated from Ancient Chinese tradition or myths, actually identifies herself with Western individuality and feminism, the paradoxical image features puzzle readers and enlighten readers. The paper is to know more and deeper about nature and meanings of these female characters according to intersubjectivity and intertextuality.
\end{abstract}

\section{Intersubjectivity}

After Husserl's transcendental phenomenology, intersubjectivity was brought up to fill the gap between subject and object in epistemology, social relation and ontology. Intersubjectivity is consensual validation between independent subjects via exchange of signals. In the backdrop of modern culture and literature practice, subjects interconnect, interplay, intervene and neutralize among themselves. In The Woman Warrior, we can see the difference and growth "I" through analysis of intersubjectivity, the more important is that the "I" in the book seeks for her identity from many "others", just parallel to the unity of "subject-object" to "I-you" in intersubjectivity .

Identity Searching. The Woman Warrior Maxine Hong Kinston deeply feels the "Identity Crisis" from 3 aspects, for her authorship as a Chisese-Amerian, the name crisis, the ethnic crisis, and life crisis according to theorist Eric Ericson. The Woman Warrior shows us the growing process of the author from identity-image, identity-denying, identity-crisis, and identity-reproduction.

Intersubjectivity is typically thought of as the communicative space between subjects, there also can lay a space between the subject as constituting and the subject as treated as an object. Literature critic Mikhail Bakhtin thought that individual consciousness was fundamentally a social process--not autonomous cognition--involving simultaneous differentiation from yet fusion with another. In another word, the other people the author created in the book and author herself are all subjective and individual in consciousness and for full-consciousness of an author is endless and indefinite, the author can accomplish her consciousness by the reflection and reaction of "othersness". At the same time, the narrators, the heroes, the other people own their rights of language, and they are not solo but polyphonic.

The Subject Consciousness Enlarging. In The Woman Warrior, the first sentence of the first chapter No Name Woman, "You must not tell anyone . . . what I am about to tell you. In China your father had a sister who killed herself. She jumped into the family well. We say that your father has all brothers because it is as if she had never been born."1 This is what the author's mother tell her but warn her not to retell. Because she is most concerned with exploring how her Chinese cultural history can be reconciled with her emerging sense of herself as an American, Kingston must uncover just what this Chinese cultural history is, and one way of doing so is by listening to, and then altering, her mother's stories about the family's Chinese past. Here, Kinston deconstructs the sole right of her mother's narration, and then deconstructs the absolute authority of one-person's telling. So No Name Woman is told by three persons-Kingston's mother, Brave Orchid, the younger "I" with curiosity and mature "I" with meditation-even more for Kingston's different 
imaginations with different tones. Her aunt's story by Kinston is still full of doubts, thoughts, comments and satire from different angles of views. Just because of this realistic-magical aspect, a talk-story can be as confusing to its audience-Kingston and her readers - as it can be inspiring. Therefore, it can help the creative subject, production subject, and accepting subject imagine the story actively, so to find self-consciousness in making up the story with their own opinions and experience. The subject consciousness is enlarged.

In The Woman Warrior, Kingston creates the polyphonic form by repositioning the idea of the novel, its truth, within multiple and various consciousnesses rather than a single consciousness and by repositioning the author of the book alongside the characters as one of these consciousnesses, creator of the characters but also their equal. Bakhtin claims that this new kind of novel is no longer a direct expression of the author's truth but an active creation of the truth in the consciousnesses of the author, the characters, and the reader, in which all participate as equals. Kingston deliberately deconstructs the fact of the stories and makes up many possibilities, so that the author and readers can find the answer by themselves as long as it makes sense. But from the polyphonic approach, we can clearly get that the No Name Woman's suicide in the cruel patriarchal society is an unavoidable tragedy at all events along with Kingston herself, of course more or less influenced by author's feminism while reading her stories and imagining her stories..

Gap Bridging. In a deeper sense, a differentiated self-consciousness is a requirement for the awareness of 'inner otherness' and 'outer otherness'. This realization will allow for a co-creative 'other' that encompasses the relationship. Such a phenomenon can evolve favorably only if one acknowledges its autonomy, its otherness. We can feel the position "I" and "otherness" change often in The Woman Warrior, there are many others, Kingston's mother, Brave Orchid, the Chinese girl student she insulted in school, the ghosts, and the white in America, and all of them play double roles in otherness in Kingston's girlhood's memoir, sometimes 'inner otherness' and sometimes 'outer otherness'. When Kingston was young, she hated her Chinese identity that embarrassed her by hindrance of speaking English, in her primary image reflected by otherness in America; she decided to learn English well as a way of realizing homogenization in American mainstream culture. Meanwhile her mother as a subject herself also is the inner otherness of Kingston, which Kingston wanted to get rid of. She can't understand her mother's manner with ghosts, keeping secrets, requiring compensation from drugstore, cutting off her fraenum, "I" here denied completely the inner otherness by Western discourse. But in her searching for Western identity, she couldn't realize the full self-consciousness in the contradiction between the subject and the inner otherness presented in intersubjectivity, which became blind part of self, so she suffered a lot in her girlhood. After growing up, Kingston gradually found the inner others came near the conscious "I", in her real life in American. Kingston experienced many kinds of discriminations by Americans in reality and pondered the real differentiation source in this multi-cultural society. During this period, her mother became an instructor, whose determination in learning medicine as a midwife and courage when facing up difficulties, especially defeating the ghost in the school, and setting up laundry in America, just inspired Kingston's struggling to hostile society, leading her to her root, her real identity. Kingston learned from Fa Mu Lan's story, she finally admitted, "I am really a dragon as she (Kingston's mother) is a Dragon, both of us in dragon years." 2 she also understood the importance of language in her silent classmates who gave up the chance of having a personality, and her aunt, Moon Orchid, who was abandoned again by her Americanized husband for her weakness and voicelessness. All of these just testified Lacan's theory; people get their true consciousness through language. By then, Kingston accepted and appreciated her double identity, both American and Chinese. When 'inner otherness' and sometimes 'outer otherness' can reconcile together or coexist individually and harmoniously, it means there are difference and many-faceted characteristics between subjects, and we can bridge the gap between subjects through connections. That is intersubjectivity, by that the subject "I" can accomplish the full subjectivity after bridging "I" and "otherness". At least Kingston think so, she ends the book "It translated well."

In the meanwhile, the readers considered as acceptation subjectivity, are influenced by the subjectivity undoubtedly. For different people, there are different understandings of the conscious 
'I". For western people, the Chinese stories are exotic style remote from American reality because of author's treating Chinese culture as "otherness", while, Chinese readers think that the author betrayed the "I" in the book to flatter the white subjectivity by making up fake Chinese stories and the "I" became the "otherness" in seeking for identity. The two same conclusion and different angles of view are the main criticism to the work. However, now more and more people begin to study how Kingston embodies these Chinese tales into the author's text, the differences and similarities between them, furthermore the culture significance it brings. That is I talk about as follows, intertextuality.

\section{Intertextuality}

We are now in a globalizing and multicultural context, which emphasize the homogeneity and diversity. The homogeneity and diversity is a pair of conflicts, and we can see more and more such conflicts appeared in modern literature, especially postmodernism. From The Woman Warrior, we can how conflicts showed in the author's life, solved or unsolved, presents an impulsive to a more harmonious and conscious subjectivity.

French literature theorist Julia Kristeva came up with the concept "intertextuality" on the basis of intersubjectivity by Mikhail Bakhtin. Some deconstructionist think the dismantling of the individual subject means the authority of narrator in a novel loses from sentence to text, hence the intertextuality. In the work of Roland Barthes, intertextuality is the concept that the meaning of an artistic work does not reside in that work.

In a word, Intertextuality in Julia Kristeva's view suggests the interdependence of texts, the continual deferment of meaning through and between texts. It is a relationship between two or more texts that quote from one another, allude to one another, or otherwise connect. Kingston's $\mathrm{Fa} \mathrm{Mu}$ Lan in The Woman Warrior is such an example. Fa Mu Lan is derived from a classical Chinese folk story about a woman named Mu-lan. Anonymously written in the fifth or sixth century by a Chinese poet, "The Ballad of Mu-lan" sketchily details how Mu-lan, about whose deeds many different versions have since been composed, fights in place of her father when he is drafted into the emperor's army. After the war ends, Mu-lan returns home to her family and resumes her normal life.

The scarcity of detail in the many versions of Mu-lan's story is markedly different than in Kingston's revision of the tale. For example, one version of "The Ballad of Mu-lan" begins with the folk heroine volunteering to fight in place of her father, whereas Kingston details Fa Mu Lan's education as a woman warrior; and Kingston's woman warrior fights against the emperor, but $\mathrm{Mu}$-lan fights for him. The woman warrior's characteristics are different from Mu Lan, who is perfect traditional female image, because she stands for challenge to conventional feudal patriarchy society as well as a loyalty for her village and her country. Similar to Mu Lan's bravery, wisdom, and diligence, however, Kingston's woman warrior has more difference. She has not Chinese factors such as hierarchy concept and feudal conventional restrictions, and she is more like a western woman warrior, a female avenger, along with random behavior, seeking for equality, eager to succeed. The more important is she identifies herself with Western individuality and feminism. Meanwhile the difference is just what her mother and she emphasizes respectively. This kind of intertextuality is a good way to understand the author's view to the difference.

Multi-culture. She blends aspects of the Chinese legend of $\mathrm{Fa} \mathrm{Mu} \mathrm{Lan} \mathrm{with} \mathrm{other} \mathrm{myths}$ stemming from Eastern philosophy and religion. For example, in her training as a woman warrior, she is under an old couple, who represent ultimate wisdom and enlightenment, like supernatural beings in Chinese myth. During the period of learning martial arts, people and swords fly through the air, based on Chinese popular culture and folklore. In a test in which she must demonstrate her survival skills in the White Tiger Mountain, a white rabbit jumped voluntarily into the fire for her food because she is very hunger. This sacrifice is what Buddhism advocates - throwing oneself into justice and humanity. After she is back to her village, her father's physically carving words into her back is a shocking act that seems a coincidental to Yue Fei's mother carving "loyalty for our country" on Yue Fei,'s back, who is a famous patriotic general in Song Dynasty, yet another 
example transplant man's morality and bravery in the woman warrior's mind. The Great Wall was also referred, on the Great Wall, she said, "I touched the Long Wall with my own fingers, running the edge of my hand between the stones, tracing the grooves the builders' hands had made. We lay our foreheads and our cheeks against the Long Wall and cried like the women who had come here looking for their men so long building the wall." 3 A simple sentence seems to echo the old tale of Lady Mengjiang. All of above enrich the content of the tale-stories full of exotic tones frankly, but bring into new type of connecting Chinese and American styles in the mean time. For example, she asks her teacher for chocolate when she is hungry, she becomes pregnant and gives birth to one baby in battle. These Chinese and American blending give us another view of the story.

Another example is the fifth chapter, "A song for Barbarian Reed Pipe", the intertextuality proves its meaning by showing that new type as an Chinese-American. After telling about her voiceless childhood and declaring her independence bravely as a mature woman, she use Ts'ai Yen's poem confirms her life as a Chinese American. "Here is a story my mother told me, not when I was young, but recently, when I told her I also talk story. The beginning is hers, the ending, mine."4 Both her mother and she can understand Ts'ai Yen's song. Ts'ai Yen, the daughter of a wealthy scholar-statesman, was a musician and a poet. she was captured by invading horsemen, whose chieftain made her his wife. For twelve years, she lived with these "barbarians" in the desert, and she even bore two children by the chieftain. Whenever the children's father would leave the family tent, Ts'ai Yen would talk and sing in Chinese to her children. Eventually, she was ransomed and returned to her family so that she could remarry and produce Han - Chinese - descendants.

Among Ts'ai Yen's writings is the lamentation "Eighteen Stanzas for a Barbarian Reed Pipe," in which Ts'ai Yen relates her life among her captors and her return to her own people. The title of The Woman Warrior's final chapter, based on Ts'ai Yen' title, suggests that Kingston identifies herself as living among "barbarians." More significant, however, is the symbolic relationship between Ts'ai Yen and Kingston's parents: Ts'ai Yen was physically forced to leave her village, and Kingston's parents, especially her father, because of depressed economic conditions in China, had no choice but to leave their homeland and seek employment in America; Ts'ai Yen characterizes her captors as barbarians, and Brave Orchid thinks all Americans are "barbarians"; and Ts'ai Yen, held captive for twelve years, sings about China and her Chinese family as a means to remember her cultural past; Brave Orchid's many talk-stories are her means of preserving her cultural past.

Although Ts'ai Yen eventually is reconciled with her family in China, Kingston only briefly notes the former captive's return to her homeland. Instead, she focuses on Ts'ai Yen's recognizing the validity of the barbarians'culture rather than on Ts'ai Yen's lamenting over her separation from her native culture. Because the barbarians and their culture symbolize Brave Orchid's perceptions of America, had Kingston dwelled on Ts'ai Yen's separation from her family and village while disparaging the nomads' culture, she would have validated the superiority, or supremacy, of a Chinese identity over an American identity; she would have justified Brave Orchid's belief that American culture is barbarous. However, by concentrating on Ts'ai Yen's recognition of and reconciliation with the nomads, Kingston suggests an ability to live harmoniously in both American and Chinese cultures. The talk-story implies not only Brave Orchid's recognition of American influences on her daughter, but also Kingston's own eventual acceptance of her Chinese past, which, after all, "translated well." This is what the term intertextuality wants to show us.

Feminsm. Of course, Kington is a feminist, her intertextuality hides in subtle relationship between female text and male text. The type of intertextuality exists in The Woman Warrior which is in opposition to the dominant culture. Although men are conspicuously, intentionally absent from The Woman Warrior. Each chapter focuses on a woman that affects Kingston's life, and in most cases depicts how that woman relates to the male-dominated society around her. In patriarchal system of language, women are voiceless. At the beginning, Kingston was influenced a lot by Chinese patriarchal concept, "Marry a rooster, and follow a rooster. Marry a dog, follow a dog. Be faithful to it Follow it."5 Later, learning from Fa Mu Lan and Ts'ai Yen, she found her identity as a female in the process of finding her own voice, so she is a woman warrior herself, and language is 
her sword. Writing is a new right, a new source of strength, according to Kingston. This is how most feminists realize their identity.

\section{Conclusion}

In intersubjectivity, individuality and community of subjects can coexist each other, it just like the heroine "I" in The Woman Warrior as a Chinese American. It is no longer contradictive or restricting each other. In the other hand, it helps readers of different regions and different generations and different genders to keep their individual subjects and common subjects in such a context. It means we can understand the book better.For intertextualiity, it improves the heritage and development of culture. On one hand, we can compare the new text with the original one, and then perceive the new text in a deeper sense. On the hand, we put the text into a lager space, it is influenced by Eastern and Western culture, it is a production of colliding and blending of multiculture.

So back to the title, who is woman warrior, the warrior motif is an extremely important part of Kingston's memoir, referring as it does to Fa Mu Lan, Brave Orchid, and Kingston herself, the reader seeking for identity in her book. Though in some ways Kingston comes up wanting comparing herself to the mythical female warrior, she discovers finally that, maybe, all of them are woman warriors, as long as she can find her voice in the multicultural society.

Through multiple voices and meanings of the polyphonic form as intersubjectivity and the artistic technique of the term intertextuallity, we found the constructing of a new narrative paradigm, which emphasizes the nationality and the special cultures of Chinese-American, declares the theme of the feminism in the novel and reflects the trend of the time.

\section{Acknowledgements}

Beihua University Youth Education Research Project "The Research and Practice of College English Teaching Humanistic Education” Project No. XJQN2016009

\section{References}

[1] C.L.Zhang, From Subjectivity to Intersubjectivity - Audience 's Orientation in Literary Studies in Multicultural Context:Journal of China West Normal University(Philosophy \& Social Sciences), 2006 (2) :36-40

[2] L.Tang, Intertextuality -the awkward memory of literature: Hubei Univerisity, 2016 No.10486

[3] C.S.Yang, The Intersubjective Turn of Literary Criticism, Academic Journal of Zhongzhou , Vol.153, (2006) No.3:236-241

[4] H.Hu, On the Inheritance and Development of Literature and Culture from Intertextuality, Academics, Vol. 1200 (2006) No. 5:205-209

[5] X.J.Huo, From "Mulan" to "Woman Warrior" - An Analysis of Kuanting 's Rewriting Chinese Stories, Journal of South China Normal University(Social Science Edition) ,Vol.2006 (4) :68-72

[6] Information on http://chin.nju.edu.cn/zwx/zhouxian/meixue9/13.mht

[7 Information on http://www.deepspirit.com/sys-tmpl/intersubjectivity/

[8] Ruth Y Jenins, Authorizing female voice and experience, Melus, Vol.19 (1994).No.3:61-73

[9] Maxine Hong Kingston, Woman Warrior, Knopf, US. 1976, P. Chapter1,2,3,5 